\title{
The pleiotropic effects of the hydroxy-methyl- glutaryl-CoA reductase inhibitors in renal disease
}

This article was published in the following Dove Press journal: International Journal of Nephrology and Renovascular Disease 28 March 2014

Number of times this article has been viewed

\author{
Sabas I Gomez' \\ Christos G Mihos ${ }^{2}$ \\ Andres M Pineda ${ }^{2}$ \\ Orlando Santana ${ }^{2}$ \\ 'Department of Internal Medicine, \\ Mount Sinai Medical Center, \\ ${ }^{2}$ Columbia University Division \\ of Cardiology, Mount Sinai Heart \\ Institute, Miami Beach, FL, USA
}

Correspondence: Orlando Santana Echocardiography Laboratory, Mount Sinai Heart Institute, 4300 Alton Road, Miami Beach, FL, 33|40, USA

Tel +l 3056742168

Fax +I 3056742368

Email osantana@msmc.com

\begin{abstract}
It is well known that statins exert their main effect by inhibiting cholesterol synthesis through the inhibition of the 3-hydroxy-3-methyl-glutaryl-CoA reductase enzyme. The pleiotropic effects of statins, which are independent of their inhibition of cholesterol synthesis, have explained many of the beneficial effects of these drugs in a variety of disorders such as malignancies, infection, and sepsis, as well as in cardiovascular and rheumatologic disorders. However, the role of these drugs in renal disorders remains controversial. In the present review, we examine the most recent findings involving statins and renal disease among different clinical scenarios, including chronic kidney disease, contrast-induced nephropathy, renal injury after coronary artery bypass surgery, and renal transplant patients.
\end{abstract}

Keywords: kidney disease, statins, renal transplant

\section{Introduction}

The main use of the 3-hydroxy-3-methyl-glutaryl-CoA reductase enzyme inhibitors (statins) is in the primary and secondary prevention of coronary artery disease and stroke. ${ }^{1,2}$ However, the overall benefits observed with statins appear to be greater than what might be expected from changes in lipid levels alone, suggesting effects beyond cholesterol lowering. ${ }^{3}$ These cholesterol-independent, or "pleiotropic" effects of statins, provide benefits in a wide range of disease processes, including cardiovascular disorders, malignancies, central nervous system disorders, infection, sepsis, and rheumatologic disorders. ${ }^{3-12}$

Statins achieve their main effect via the inhibition of the enzyme 3-hydroxy-3methyl-glutaryl-CoA reductase, decreasing the synthesis of cholesterol and isoprenoids, and upregulating the production of endothelial nitric oxide synthase. ${ }^{13,14}$ There is also decreased production of nicotinamide dinucleotide phosphate oxidase that results in fewer free oxygen radicals in the systemic circulation. ${ }^{13}$ By inhibiting L-mevalonic acid synthesis, statins decrease the amount of isoprenoid intermediates that have a direct role in intracellular signaling. This, in turn, has a positive impact on inflammation, cell proliferation, and vasodilatation (Figure 1). Numerous other mechanisms appear to be involved in the statin pleiotropy, including immunomodulatory properties, sympathetic system normalization, inhibition of platelet aggregation, and regulation of the blood coagulation cascade. ${ }^{15-17}$ The following is a review of the current literature and recent studies regarding the potential benefits of statins on renal function and disease.

\section{General effects of statins on renal function}

The importance of nitric oxide in the autoregulation of renal vasculature is well established. ${ }^{18-20}$ Focused on the observation that impaired endothelial vasodilatation 


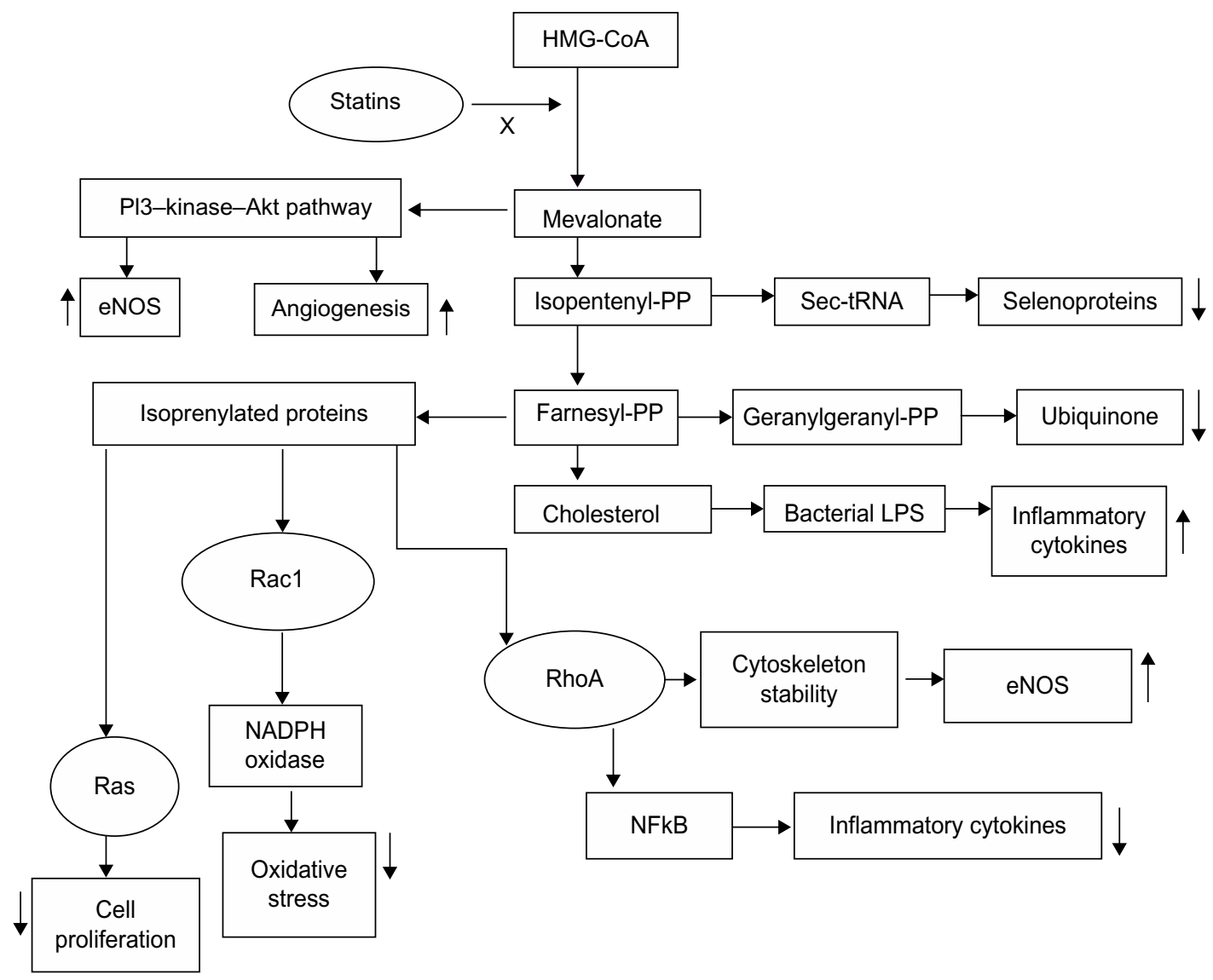

Figure I Effect of statins over the isoprenyl derivatives.

Abbreviations: HMG-CoA, 3-hydroxy-3-methyl-glutaryl-CoA; PI3, phosphorous triiodide; Akt, protein kinase B; eNOS, endothelial nitric oxide synthase; PP, pyrophosphate; tRNA, transfer ribonucleic acid; LPS, lipopolysaccharide; Racl, Ras-related C3 botulinum toxin substrate I; RhoA, Ras homologue gene family member A; NADPH, nicotinamide adenine dinucleotide phosphate; NFkB, nuclear factor-kappa B.

represents an early manifestation of atherosclerosis, Ott et $\mathrm{al}^{21}$ investigated the effects of rosuvastatin on renal vasculature in 40 hypercholesterolemic patients. In this double-blind, randomized, placebo-controlled trial, the investigators studied the effect of 6-week treatment with $10 \mathrm{mg}$ of rosuvastatin daily versus placebo on basal nitric oxide synthase activity of the renal vasculature. This was assessed by measuring renal plasma flow, both before and after the blockade of nitric oxide synthase, with systemic infusion of NG-monomethyl-L-arginine. The decrease in renal plasma flow in response to $\mathrm{N}(\mathrm{G})$-monomethyl-L-arginine was significantly more pronounced in the statin group $(-13.7 \%$ $\pm 1 \%$ versus $-11.3 \% \pm 0.7 \% ; P=0.046$ ).

In the JUPITER (Justification for the Use of Statins in Prevention: An Intervention Trial Evaluating Rosuvastatin) study, ${ }^{22}$ nearly 18,000 healthy men and women with a lowdensity lipoprotein level $<130 \mathrm{mg} / \mathrm{dL}$ and C-reactive protein level $>2.0 \mathrm{mg} / \mathrm{L}$ were randomized to $20 \mathrm{mg}$ of rosuvastatin or placebo daily for a 2-year treatment period. In patients with serum creatinine levels lower than $2 \mathrm{mg} / \mathrm{dL}$ and no diabetes mellitus, a reduction was seen in the estimated glomerular filtration rate (eGFR) of approximately $0.5 \mathrm{~mL} /$ minute $/ 1.73 \mathrm{~m}^{2}$ in the placebo compared with the rosuvastatin group at 1 year $(P<0.004)$. The most significant reductions were seen in patients with a baseline eGFR $>60 \mathrm{~mL} /$ minute $/ 1.73 \mathrm{~m}^{2} .{ }^{23}$ These results support the use of statins in patients at increased risk for cardiovascular or renal disease (Table 1).

\section{Effect of statins on renal function in patients with cardiovascular disease}

Various studies have evaluated the effects of statins on renal function in patients with established cardiovascular disease or with cardiovascular risk factors. In the TNT (Treating to New Targets) study, ${ }^{24}$ a total of 10,001 patients with stable ischemic heart disease were randomized to low-dose $(10 \mathrm{mg}$ of atorvastatin daily) versus intensive ( $80 \mathrm{mg}$ of atorvastatin daily) statin therapy for a mean duration of 5 years. In a post hoc analysis evaluating statin dosing effects on long-term renal function, mean eGFR showed an increase of $5.2 \pm 0.14 \mathrm{~mL} /$ minute $/ 1.73 \mathrm{~m}^{2}$ with the $80 \mathrm{mg}$ dose versus 
Table I Randomized trials on the use of statins in patients with chronic renal disease

\begin{tabular}{|c|c|c|c|c|}
\hline Study & $\mathbf{n}$ & Statin & $\begin{array}{l}\text { Baseline eGFR } \\
\text { (mL/minute) }\end{array}$ & Results \\
\hline JUPITER ${ }^{22}$ & 17,802 & Rosuvastatin $20 \mathrm{mg}$ versus placebo & 73.3 & Did not show any benefit on eGFR. \\
\hline $\mathrm{TNT}^{25}$ & $10,00 \mid$ & Atorvastatin $10 \mathrm{mg}$ versus $80 \mathrm{mg}$ & 65.6 & $\begin{array}{l}\text { Atorvastatin protected against the } \\
\text { expected } 5 \text {-year decline in renal function. }\end{array}$ \\
\hline ASCOT-LLA ${ }^{26}$ & 10,305 & Atorvastatin $10 \mathrm{mg}$ versus placebo & 69.5 & $\begin{array}{l}\text { Adding atorvastatin to antihypertensive } \\
\text { medications appears to slow down age- } \\
\text { related decline in kidney function. }\end{array}$ \\
\hline ATTEMPT $^{38}$ & 1,123 & Atorvastatin $10-80 \mathrm{mg}$ versus placebo & 69.6 & $\begin{array}{l}\text { Atorvastatin improved eGFR in metabolic } \\
\text { syndrome patients. }\end{array}$ \\
\hline PLANET ${ }^{41}$ & 353 & $\begin{array}{l}\text { Rosuvastatin } 10 \mathrm{mg} \text { versus } \\
40 \mathrm{mg} \text { versus atorvastatin } 80 \mathrm{mg}\end{array}$ & 71.2 & $\begin{array}{l}\text { None of the treatments showed any } \\
\text { protection against GFR decline in diabetes } \\
\text { mellitus patients. }\end{array}$ \\
\hline PLANET $2^{42}$ & 237 & $\begin{array}{l}\text { Rosuvastatin } 10 \mathrm{mg} \text { versus } \\
40 \mathrm{mg} \text { versus atorvastatin } 80 \mathrm{mg}\end{array}$ & 74.9 & $\begin{array}{l}\text { Neither treatment showed any protection } \\
\text { against GFR decline in nondiabetic } \\
\text { patients. }\end{array}$ \\
\hline SHARP 45 & 9,370 & $\begin{array}{l}\text { Simvastatin } 20 \mathrm{mg}+\text { ezetimibe } \\
10 \mathrm{mg} \text { versus placebo }\end{array}$ & 26.6 & No differences in renal outcomes. \\
\hline LORD $^{46}$ & 132 & Atorvastatin $10 \mathrm{mg}$ versus placebo & 31.9 & No significant change was found. \\
\hline
\end{tabular}

Abbreviations: n, number; eGFR, estimated glomerular filtration rate; JUPITER, the Justification for the Use of Statins in Prevention: An Intervention Trial Evaluating Rosuvastatin study; TNT, Treating to New Targets study; ASCOT-LLA, Anglo-Scandinavian Cardiac Outcomes Trial - Lipid Lowering Arm; ATTEMPT, Assessing The Treatment Effect in Metabolic Syndrome Without Perceptible Diabetes Trial; GFR, glomerular filtration rate; PLANET I, Prospective Evaluation of Proteinuria and Renal Function in Diabetic Patients with Progressive Renal Disease; PLANET 2, Prospective Evaluation of Proteinuria and Renal Function in Non-Diabetic Patients with Progressive Renal Disease; SHARP, Study of Heart And Renal Protection; LORD, Lipid-lowering and Onset of Renal Disease trial.

$3.5 \pm 0.14 \mathrm{~mL} /$ minute $/ 1.73 \mathrm{~m}^{2}$ with the $10 \mathrm{mg}$ dose at a median follow-up of 59.6 months, representing a change of $1.68 \pm 0.2 \mathrm{~mL} / \mathrm{minute} / 1.7 \mathrm{~m}^{2}(P<0.0001){ }^{25}$

The benefits on kidney function by adding statins to hypertensive patients at high risk for developing cardiovascular disease was also evaluated. In the ASCOT-LLA (Anglo-Scandinavian Cardiac Outcomes Trial - Lipid Lowering Arm) study, ${ }^{26}$ a total of 10,305 patients with essential hypertension and three or more risk factors for cardiovascular disease were randomized to receive atorvastatin (10 $\mathrm{mg}$ ) versus placebo, in conjunction with either amlodipine or atenolol. Over a median follow-up of 3.3 years, the use of atorvastatin was associated with significant improvement in the eGFR as compared with placebo, regardless of the antihypertensive treatment regimen used. The mean eGFR improved in the amlodipine/atorvastatin group by +0.23 (95\% confidence interval [CI]: $0.01-0.45 \mathrm{~mL} /$ minute; $P=0.037)$ and by +0.22 (95\% CI: $0.00-0.44 \mathrm{~mL} /$ minute; $P=0.046$ ) for the atenolol/atorvastatin group, respectively.

\section{Patients undergoing cardiac surgery}

It has been hypothesized that the use of statins, through their pleiotropic effects, may reduce the incidence of acute kidney injury postoperatively. In a retrospective analysis, Virani et $\mathrm{al}^{27}$ examined the relationship between preoperative statin therapy and the risk of postoperative renal insufficiency in 3,001 patients undergoing cardiac surgery, 1,675 of whom were on a statin regimen. Preoperative use of statins was associated with a significant reduction in the risk of postoperative renal insufficiency (odds ratio [OR]: 0.6 ; 95\% CI: $0.38-0.95 ; P=0.03)$. In a separate retrospective study of 2,760 patients undergoing coronary artery bypass graft surgery, of whom 1,557 were on active statin treatment, preoperative use of statins was associated with a reduction in the need for postoperative hemodialysis $(1.9 \%$ versus $3.6 \% ; P=0.01)$ and decreased in-hospital mortality $(2.4 \%$ versus $4.2 \%$; $P=0.008$ ), as compared to nonstatin users. Overall statin therapy was associated with $43 \%$ and $46 \%$ reductions in the risk of death or requirement for hemodialysis, respectively $(P<0.001$ for both $) .^{28}$

Conversely, a substantial amount of published data has challenged the true efficacy of statins in preventing renal injury postcardiac surgery. Prowle et $\mathrm{al}^{29}$ randomized 100 patients undergoing cardiac surgery to atorvastatin $40 \mathrm{mg}$ daily or placebo, with a follow-up of 30 months. There were no differences noted in the incidence of acute kidney injury, need for hemodialysis, or mortality. Additionally, in a retrospective study by Argalious et al, ${ }^{30}$ of 10,639 patients undergoing coronary artery bypass graft and/or valve surgery, it was observed that preoperative statin therapy did not reduce the need for postoperative dialysis or perioperative mortality, underscoring the need for large, randomized controlled trials to elucidate whether there is a role for routine treatment with statins during cardiac surgery. 


\section{Use of statins in chronic kidney disease}

Chronic inflammatory processes play an important role in the progression of chronic kidney disease (CKD) ${ }^{31-33}$ Thus, it has been postulated that statins might exert a protective effect in regards to progressive kidney damage. In theory, statins are believed to downregulate the production and renal infiltration of T-cells, T-helper cells, macrophages, and neutrophils, leading to reductions in renal inflammation, glomerular scarring, and mesangial proliferation. ${ }^{34,35}$

In the ATTEMPT (Assessing The Treatment Effect in Metabolic Syndrome Without Perceptible Diabetes) trial, ${ }^{36}$ 1,123 patients with metabolic syndrome, but without diabetes mellitus or cardiovascular disease, were randomized to atorvastatin daily in addition to multifactorial treatment (quinapril/amlodipine/hydrochlorothiazide for hypertension; metformin for impaired fasting glucose; and orlistat for obesity) and followed for 3.5 years. Atorvastatin was titrated from $10 \mathrm{mg}$ to $80 \mathrm{mg}$ daily, with a goal low-density lipoprotein cholesterol level of $<100 \mathrm{mg} / \mathrm{dL}$ (group A, number $[\mathrm{n}]=566$ ) or $<130 \mathrm{mg} / \mathrm{dL}$ (group B, $\mathrm{n}=557$ ). In a post hoc analysis of the entire study population, eGFR increased by $3.5 \%$, from $69.6 \pm 12.6 \mathrm{~mL} /$ minute $/ 1.73$ $\mathrm{m}^{2}$ to $72.1 \pm 10.0 \mathrm{~mL} / \mathrm{minute} / 1.73 \mathrm{~m}^{2}$, and serum uric acid levels decreased by $5.6 \%(P<0.001$ for both). In the subgroup of patients with stage 3 CKD ( $=349)$, the eGFR increased by $11.1 \%$ in the group who received the higher dose of atorvastatin versus $7.5 \%$ in the group that received the lower dose $(P<0.001)$, suggesting greater renal benefit with more intensive treatment. ${ }^{37}$ In a meta-analysis by Sandhu et al, ${ }^{38}$ which included 27 studies with a total of 39,704 patients, the effects of statins on renal function and urinary protein excretion in patients with $\mathrm{CKD}$, excluding those with end-stage renal disease, were assessed. Statin therapy attenuated the rate of eGFR decline by $1.22 \mathrm{~mL} /$ minute/year (95\% CI: 0.44-2.0) in statin recipients compared with placebo, mainly driven by its effect in patients with established cardiovascular disease $(0.93 \mathrm{~mL} /$ minute per year slower than control subjects; 95\% CI: 0.10-1.76). Data have also shown a reduction in all-cause mortality and cardiovascular mortality, as well as decreased 24-hour urinary protein excretion, in statin users with $\mathrm{CKD} .{ }^{39} \mathrm{Simi}-$ lar to these results are the ones obtained by Bianchi et $\mathrm{al}^{40}$ evaluating the effect of statins on proteinuria in patients with CKD. In a prospective fashion, atorvastatin therapy was compared to placebo in 56 patients with CKD over a 1-year treatment period. All patients had been treated for 1 year with angiotensin-converting enzyme (ACE) inhibitors or angiotensin II receptor antagonists and other antihypertensive drugs. By the end of the 1-year treatment, urine protein excretion decreased from $2.2 \pm 0.1 \mathrm{~g}$ to $1.2 \pm 1.0 \mathrm{~g}$ every 24 hours $(P<0.01)$ in patients treated with atorvastatin, and the effect was additive to those of treatment with ACE inhibitors and angiotensin AT1 receptor antagonists.

Several randomized trials have challenged the findings of the ATTEMPT investigators ${ }^{36}$ and others. In the recently completed 52-week PLANET 1 (Prospective Evaluation of Proteinuria and Renal Function in Diabetic Patients with Progressive Renal Disease) and PLANET 2 (Prospective Evaluation of Proteinuria and Renal Function in Non-diabetic Patients with Progressive Renal Disease) trials, ${ }^{41,42}$ diabetic $(n=325)$ and nondiabetic $(n=220)$ patients with progressive renal dysfunction were assigned to rosuvastatin $10 \mathrm{mg}$, rosuvastatin $40 \mathrm{mg}$, or atorvastatin $80 \mathrm{mg}$ daily, with all patients on baseline ACE inhibitor or aldosterone receptor blocker therapy. Patients with severe renal disease or uncontrolled diabetes mellitus were excluded. Combining the results from PLANET 1 and PLANET 2 revealed the following: 1) $80 \mathrm{mg}$ of atorvastatin daily reduced proteinuria by $20 \%$, but had no effect of eGFR; 2) $10 \mathrm{mg}$ or $40 \mathrm{mg}$ of rosuvastatin daily did not significantly impact proteinurea; and 3) $40 \mathrm{mg}$ of rosuvastatin daily appeared to reduce eGFR by $8 \mathrm{~mL} /$ minute $/ 1.73 \mathrm{~m}^{2}$ per year. The different results on eGFR in these two trials seem to seem to suggest that different statins have different effects. However, in a meta-analysis involving 16 trials and 24,278 patients evaluating the effects of rosuvastatin and atorvastatin, it was shown that both drugs improved eGFR significantly when compared with controls, and there was no significant difference in the head-to-head comparison. ${ }^{43}$ Ongoing clinical trials comparing these two drugs will likely help elucidate potential differences among statins. $^{44}$

The SHARP (Study of Heart And Renal Protection) trial ${ }^{45}$ randomized 9,270 patients with advanced kidney disease to $20 \mathrm{mg}$ of simvastatin plus $10 \mathrm{mg}$ of ezetimibe daily versus placebo, for a treatment period of nearly 5 years. While the relative risk of major adverse events was decreased by $17 \%$ $(P=0.0021)$ in patients receiving simvastatin and ezetimibe, there was no difference between the groups in terms of the rate of progression to end-stage renal disease. Finally, these results were further confirmed in the LORD (Lipid lowering and Onset of Renal Disease) trial, ${ }^{46}$ which revealed no benefit of atorvastatin use on renal function in 132 patients with CKD. The available data on statin use in patients with CKD 
has provided equivocal results, and their true benefit remains to be established.

\section{Statins in contrast-induced nephropathy}

The development of contrast-induced nephropathy (CIN) is a serious complication associated with radiographic procedures that usually begins shortly after the administration of contrast media. ${ }^{47,48}$ The incidence of CIN varies and mainly depends on comorbidities, such as baseline renal insufficiency, diabetes mellitus, and chronic heart failure, as well as on the type of contrast medium used. ${ }^{49-51}$ Toxic effect to the renal tubules, as well as decreased renal medullary blood flow, has been implicated in this phenomenon. ${ }^{52}$ Since there is no specific management for renal insufficiency after the development of CIN, there is an interest in evaluating preventive strategies.

In the ARMYDA-CIN (Atorvastatin For Reduction of Myocardial Damage During Angioplasty-Contrast-Induced Nephropathy) trial, ${ }^{53} 241$ patients with acute coronary syndrome undergoing percutaneous coronary intervention were randomized to receive $80 \mathrm{mg}$ of atorvastatin 12 hours before the procedure, followed by $40 \mathrm{mg}$ of atorvastatin or placebo immediately preprocedure, with both groups receiving long-term atorvastatin at a dose of $40 \mathrm{mg}$ daily. Use of preprocedure atorvastatin conferred a $66 \%$ reduction in the risk of CIN $(P=0.043)$ and shorter hospital length of stay $(P=0.007)$, as well as a lower postprocedure serum creatinine level as compared to placebo $(1.06 \pm 0.35 \mathrm{mg} / \mathrm{dL}$ versus $1.12 \pm 0.27 \mathrm{mg} / \mathrm{dL}$ in placebo; $P=0.01)$. A retrospective study was conducted by Khanal et al, ${ }^{54}$ which included a total of 29,409 patients undergoing percutaneous coronary intervention who were evaluated for preprocedure statin use and impact on CIN. Patients on baseline statin therapy had a 13\% reduced risk of developing $\mathrm{CIN}$, and a $35 \%$ reduction in the incidence of hemodialysis ( $P=0.03$ for both). However, the data from ARMYDA-CIN ${ }^{53}$ and Khanal et $\mathrm{al}^{54}$ was challenged by two meta-analyses, ${ }^{55,56}$ both of which failed to demonstrate a protective role of statins in reducing the incidence of CIN among patients undergoing coronary angiography, despite observed reductions in postprocedure serum creatinine.

\section{Statins and renal transplant}

Renal transplant recipients experience premature cardiovascular disease and death. Inflammatory markers such as interleukin-6 and C-reactive protein are elevated in this population, and are independently associated with major cardiovascular events and all-cause mortality. ${ }^{32}$ Due to their antiinflammatory effects and protective role in preventing ischemia-reperfusion injury, it has been hypothesized that statins may provide beneficial effects in renal transplant recipients. ${ }^{57}$

The one major randomized trial conducted on the effects of statins on renal transplant recipients was the ALERT (Assessment of Lescol in Renal Transplant) trial. ${ }^{58}$ A total of 2,102 posttransplant patients were randomized to either $40 \mathrm{mg}$ daily of fluvastatin or placebo, with a mean follow-up of 5 years. The use of fluvastatin did not impact the rates of renal graft loss or of declining renal function. A metaanalysis by Palmer et $\mathrm{al}^{59}$ included 16 studies comparing statin use versus placebo in renal transplant recipients with a total of 3,329 patients. While beneficial effects were observed in terms of reduced serum cholesterol levels and an apparent trend toward decreased cardiovascular mortality, statin therapy did not affect the incidence of acute graft rejection. Similar findings were reported by Reiling et $\mathrm{al},{ }^{60}$ who conducted a retrospective study of 266 renal transplant recipients on statin treatment, and found no difference in the incidence of acute or delayed graft rejection as compared to placebo. Thus, the role of statin therapy in patients with renal transplantation remains inconclusive.

\section{Discussion}

Evidence for statin use in the prevention and treatment of renal disorders is a topic of much interest for clinicians. However, data remain inconclusive, and many of the studies are limited due to a lack of randomization, heterogeneity, and conflicting results. It might be the case that not all of them share the same properties, and that may account, at least to some extent, for the observed differences among studies. Another factor to be considered is that the dosing of these medications is not homogeneous among trials, which can also add to the heterogeneity mentioned above. Presently, there are several randomized clinical trials being conducted that may clarify the indications for statin therapy in different renal pathologies, in order to elucidate the possible pleiotropic mechanisms that would confer any potential benefits (Table 2). ${ }^{44,61-66}$ These studies, in addition to the existing clinical data, should lay the groundwork for future guidelines and recommendations for the use of statins in patients with renal disorders.

\section{Disclosure}

The authors report no conflicts of interest in this work. 
Table 2 Ongoing clinical trials on the use of statins and renal function

\begin{tabular}{|c|c|c|c|c|}
\hline Study & $\begin{array}{l}\text { Estimated } \\
\text { enrollment }\end{array}$ & Statin & $\begin{array}{l}\text { Baseline eGFR } \\
\text { (mL/minute) }\end{array}$ & Endpoint \\
\hline PRATO-ACS 2 study ${ }^{44}$ & 760 & $\begin{array}{l}\text { Rosuvastatin } 40 \mathrm{mg} \\
\text { followed by } 20 \mathrm{mg} / \text { day versus } \\
\text { atorvastatin ( } 80 \mathrm{mg} \text { followed } \\
\text { by } 40 \mathrm{mg} / \text { day) }\end{array}$ & $\begin{array}{l}\text { Any, except ESRD } \\
\text { or AKI }\end{array}$ & $\begin{array}{l}\text { To compare the nephroprotective } \\
\text { effects of high-dose atorvastatin and } \\
\text { high-dose rosuvastatin. }\end{array}$ \\
\hline $\begin{array}{l}\text { Anti-inflammatory and } \\
\text { renoprotective effect of } \\
\text { pretreatment loading dose } \\
\text { atorvastatin in CABG }\end{array}$ & 80 & $\begin{array}{l}\text { Load of atorvastatin } 80 \mathrm{mg}+ \\
40 \mathrm{mg}\end{array}$ & GFR $>60 \mathrm{~mL} /$ minute & $\begin{array}{l}\text { Safety and efficiency study of loading } \\
\text { dose of atorvastatin in cardiac } \\
\text { surgery. }\end{array}$ \\
\hline $\begin{array}{l}\text { Short-term atorvastatin's } \\
\text { effect on acute kidney injury } \\
\text { following cardiac surgery }{ }^{62}\end{array}$ & 820 & $\begin{array}{l}\text { Atorvastatin } 80 \mathrm{mg} \text { (load), } \\
\text { followed by } 40 \mathrm{mg} / \text { day }\end{array}$ & Any, except ESRD & $\begin{array}{l}\text { Short-term atorvastatin's effect on } \\
\text { acute kidney injury following cardiac } \\
\text { surgery. }\end{array}$ \\
\hline PRINCIPLE-II study ${ }^{63}$ & 404 & $\begin{array}{l}\text { Pitavastatin } 4 \mathrm{mg} / \text { day for } \\
7 \text { days before angiography }\end{array}$ & eGFR $\leq 60 \mathrm{~mL} /$ minute & $\begin{array}{l}\text { Preventive effect of pitavastatin on } \\
\text { contrast-induced nephropathy in } \\
\text { patients with renal dysfunction. }\end{array}$ \\
\hline SARP study ${ }^{64}$ & 40 & $\begin{array}{l}\text { Atorvastatin } 40 \mathrm{mg} \text { versus } \\
10 \mathrm{mg}\end{array}$ & CKD stage $3-4$ & $\begin{array}{l}\text { To evaluate the comparative } \\
\text { effects of low-dose atorvastatin on } \\
\text { proteinuria in patients with stage } 3 \text { or } \\
4 \text { chronic kidney disease. }\end{array}$ \\
\hline SCIN study ${ }^{65}$ & 200 & $\begin{array}{l}\text { Load of atorvastatin } \\
80 \mathrm{mg}+40 \mathrm{mg}\end{array}$ & $\begin{array}{l}\text { Creatinine }>1.3 \mathrm{mg} / \mathrm{dL} \\
\text { or GFR }<60 \mathrm{~mL} / \mathrm{minute}\end{array}$ & $\begin{array}{l}\text { To determine if statin therapy plus } \\
\text { intravenous normal saline, in patients } \\
\text { with CKD undergoing angiography, is } \\
\text { superior to placebo plus intravenous } \\
\text { normal saline therapy in the } \\
\text { prevention of CIN. }\end{array}$ \\
\hline
\end{tabular}

Abbreviations: eGFR, estimated glomerular filtration rate; PRATO-ACS 2, Atorvastatin Versus Rosuvastatin on Contrast Induced Acute Kidney Injury; ESRD, end-stage renal disease; AKI, acute kidney injury; CABG, coronary artery bypass graft; GFR, glomerular filtration rate; PRINCIPLE-II, Preventive Effect of the PRetreatment With pitavastatiN on Contrast-Induced Nephropathy in Patients With RenaL Dysfunction UndErgoing Coronary Angiography/lntervention; SARP, Study of Atorvastatin Dose Dependent Reduction of Proteinuria; CKD, chronic kidney disease; SCIN, Efficacy of Statins In Prevention of CIN; CIN, contrast-induced nephropathy.

\section{References}

1. Pignone M, Phillips C, Mulrow C. Use of lipid lowering drugs for primary prevention of coronary heart disease: meta-analysis of randomised trials. BMJ. 2000;321(7267):983-986.

2. Prevention of cardiovascular events and death with pravastatin in patients with coronary heart disease and a broad range of initial cholesterol levels. The Long-Term Intervention with Pravastatin in Ischaemic Disease (LIPID) Study Group. $N$ Engl $J$ Med. 1998;339(19):1349-1357.

3. Mihos CG, Salas MJ, Santana O. The pleiotropic effects of the hydroxymethyl-glutaryl-CoA reductase inhibitors in cardiovascular disease: a comprehensive review. Cardiol Rev. 2010;18(6):298-304.

4. Mihos CG, Santana O. Pleiotropic effects of the HMG-CoA reductase inhibitors. Int J Gen Med. 2011;4:261-271.

5. Cleland JG, McMurray JJ, Kjekshus J, et al; CORONA Study Group. Plasma concentration of amino-terminal pro-brain natriuretic peptide in chronic heart failure: prediction of cardiovascular events and interaction with the effects of rosuvastatin: a report from CORONA (Controlled Rosuvastatin Multinational Trial in Heart Failure). J Am Coll Cardiol. 2009;54(20):1850-1859.

6. Barrios V, Escobar C. Rosuvastatin along the cardiovascular continuum: from JUPITER to AURORA. Expert Rev Cardiovasc Ther. 2009;7(11): $1317-1327$

7. Dobesh PP, Klepser DG, McGuire TR, Morgan CW, Olsen KM. Reduction in mortality associated with statin therapy in patients with severe sepsis. Pharmacotherapy. 2009;29(6):621-630.

8. Zeichner S, Mihos CG, Santana O. The pleiotropic effects and therapeutic potential of the hydroxy-methyl-glutaryl-CoA reductase inhibitors in malignancies: a comprehensive review. J Cancer Res Ther. 2012;8(2):176-183.
9. Yanuck D, Mihos CG, Santana O. Mechanisms and clinical evidence of the pleiotropic effects of the hydroxy-methyl-glutaryl-CoA reductase inhibitors in central nervous system disorders: a comprehensive review. Int J Neurosci. 2012;122(11):619-629.

10. Mihos CG, Artola RT, Santana O. The pleiotropic effects of the hydroxymethyl-glutaryl-CoA reductase inhibitors in rheumatologic disorders: a comprehensive review. Rheumatol Int. 2012;32(2):287-294.

11. Lazzerini PE, Lorenzini S, Selvi E, et al. Simvastatin inhibits cytokine production and nuclear factor-kB activation in interleukin 1beta-stimulated synoviocytes from rheumatoid arthritis patients. Clin Exp Rheumatol. 2007;25(5):696-700.

12. Tikiz C, Utuk O, Pirildar T, et al. Effects of Angiotensin-converting enzyme inhibition and statin treatment on inflammatory markers and endothelial functions in patients with longterm rheumatoid arthritis. J Rheumatol. 2005;32(11):2095-2101.

13. Endres M. Statins and stroke. J Cereb Blood Flow Metab. 2005;25(9): 1093-1110.

14. Liao JK. Beyond lipid lowering: the role of statins in vascular protection. Int J Cardiol. 2002;86(1):5-18.

15. Li J, Li JJ, He JG, Nan JL, Guo YL, Xiong CM. Atorvastatin decreases C-reactive protein-induced inflammatory response in pulmonary artery smooth muscle cells by inhibiting nuclear factor-kappaB pathway. Cardiovasc Ther. 2010;28(1):8-14.

16. Iwata A, Shirai R, Ishii H, et al. Inhibitory effect of statins on inflammatory cytokine production from human bronchial epithelial cells. Clin Exp Immunol. 2012;168(2):234-240.

17. Luzak B, Rywaniak J, Stanczyk L, Watala C. Pravastatin and simvastatin improves acetylsalicylic acid-mediated in vitro blood platelet inhibition. Eur J Clin Invest. 2012;42(8):864-872. 
18. Jin C, Hu C, Polichnowski A, et al. Effects of renal perfusion pressure on renal medullary hydrogen peroxide and nitric oxide production. Hypertension. 2009;53(6):1048-1053.

19. Cowley AW Jr. Renal medullary oxidative stress, pressure-natriuresis, and hypertension. Hypertension. 2008;52(5):777-786.

20. Zhen J, Lu H, Wang XQ, Vaziri ND, Zhou XJ. Upregulation of endothelial and inducible nitric oxide synthase expression by reactive oxygen species. Am J Hypertens. 2008;21(1):28-34.

21. Ott C, Schlaich MP, Schmidt BM, Titze SI, Schäufele T, Schmieder RE. Rosuvastatin improves basal nitric oxide activity of the renal vasculature in patients with hypercholesterolemia. Atherosclerosis. 2008;196(2): 704-711.

22. Ridker PM, Danielson E, Fonseca FA, et al; JUPITER Study Group. Rosuvastatin to prevent vascular events in men and women with elevated C-reactive protein. $N$ Engl J Med. 2008;359(21): 2195-2207.

23. Vidt DG, Ridker PM, Monyak JT, Schreiber MJ, Cressman MD. Longitudinal assessment of estimated glomerular filtration rate in apparently healthy adults: a post hoc analysis from the JUPITER study (justification for the use of statins in prevention: an intervention trial evaluating rosuvastatin). Clin Ther. 2011;33(6):717-725.

24. LaRosa JC, Grundy SM, Waters DD, et al; Treating to New Targets (TNT) Investigators. Intensive lipid lowering with atorvastatin in patients with stable coronary disease. $N$ Engl J Med. 2005;352(14): 1425-1435.

25. Shepherd J, Kastelein JJ, Bittner V, et al; Treating to New Targets Investigators. Effect of intensive lipid lowering with atorvastatin on renal function in patients with coronary heart disease: the Treating to New Targets (TNT) study. Clin J Am Soc Nephrol. 2007;2(6): 1131-1139.

26. Gupta AK, Chang CL, Collier B, et al. The relationship between statin therapy and progression of renal damage among 10305 hypertensive patients randomised in the ASCOT-lipid-lowering arm (LLA). Atheroscl Suppl. 2011;12(1):158-159.

27. Virani SS, Nambi V, Polsani VR, et al. Preoperative statin therapy decreases risk of postoperative renal insufficiency. Cardiovasc Ther. 2010;28(2):80-86.

28. Huffmyer JL, Mauermann WJ, Thiele RH, Ma JZ, Nemergut EC. Preoperative statin administration is associated with lower mortality and decreased need for postoperative hemodialysis in patients undergoing coronary artery bypass graft surgery. J Cardiothorac Vasc Anesth. 2009;23(4):468-473.

29. Prowle JR, Calzavacca P, Licari E, et al. Pilot double-blind, randomized controlled trial of short-term atorvastatin for prevention of acute kidney injury after cardiac surgery. Nephrology (Carlton). 2012;17(3): 215-224.

30. Argalious M, Xu M, Sun Z, Smedira N, Koch CG. Preoperative statin therapy is not associated with a reduced incidence of postoperative acute kidney injury after cardiac surgery. Anesth Analg. 2010;111(2) 324-330.

31. Krane V, Wanner C. Statins, inflammation and kidney disease. Nat Rev Nephrol. 2011;7(7):385-397.

32. Abedini S, Holme I, März W, et al; ALERT study group. Inflammation in renal transplantation. Clin J Am Soc Nephrol. 2009;4(7):1246-1254.

33. Hung AM, Crawford DC, Griffin MR, et al; AASK Study Group. CRP polymorphisms and progression of chronic kidney disease in African Americans. Clin J Am Soc Nephrol. 2010;5(1):24-33.

34. Eller P, Eller K, Wolf AM, et al. Atorvastatin attenuates murine anti-glomerular basement membrane glomerulonephritis. Kidney Int. 2010;77(5):428-435.

35. Kostapanos MS, Liberopoulos EN, Elisaf MS. Statin pleiotropy against renal injury. J Cardiometab Syndr. 2009;4(1):E4-E9.

36. Athyros VG, Ganotakis E, Kolovou GD, et al. Assessing The Treatment Effect in Metabolic Syndrome Without Perceptible Diabetes (ATTEMPT) Collaborative. Assessing the treatment effect in metabolic syndrome without perceptible diabetes (ATTEMPT): a prospective-randomized study in middle aged men and women. Curr Vasc Pharmacol. 2011;9(6):647-657.
37. Athyros VG, Karagiannis A, Ganotakis ES, et al. Assessing The Treatment Effect in Metabolic syndrome without Perceptible diabeTes (ATTEMPT) Collaborative Group. Association between the changes in renal function and serum uric acid levels during multifactorial intervention and clinical outcome in patients with metabolic syndrome. A post hoc analysis of the ATTEMPT study. Curr Med Res Opin. 2011;27(8):1659-1668.

38. Sandhu S, Wiebe N, Fried LF, Tonelli M. Statins for improving renal outcomes: a meta-analysis. J Am Soc Nephrol. 2006;17(7):2006-2016.

39. Navaneethan SD, Pansini F, Perkovic V, et al. HMG CoA reductase inhibitors (statins) for people with chronic kidney disease not requiring dialysis. Cochrane Database Syst Rev. 2009CD007784.

40. Bianchi S, Bigazzi R, Caiazza A, Campese VM. A controlled, prospective study of the effects of atorvastatin on proteinuria and progression of kidney disease. Am J Kidney Dis. 2003;41(3):565-570.

41. AstraZeneca. Randomized, double-blind, 52-wk, parallel-grp, multicentre, PIIb study to evaluate effects of rosuvastatin $10 \mathrm{mg}$, rosuvastatin $40 \mathrm{mg}$ and atorvastatin $80 \mathrm{mg}$ on urinary protein excretion in hypercholesterolaemic diabetic patients with moderate proteinuria. NLM identifier: NCT00296374

42. AstraZeneca. Randomized, double-blind, 52-wk, parallel-grp multicentre, PIIb study to evaluate effects of rosuvastatin $10 \mathrm{mg}$, rosuvastatin $40 \mathrm{mg}$ and atorvastatin $80 \mathrm{mg}$ on urinary protein excretion in hypercholesterolaemic non-diabetic patients with moderate proteinuria. NLM identifier: NCT00296400.

43. Wu Y, Wang Y, An C, et al. Effects of rosuvastatin and atorvastatin on renal function: meta-analysis. Circ J. 2012;76(5):1259-1266.

44. Randomized, double-blind, parallel-grp. Atorvastatin versus rosuvastatin on contrast induced acute kidney injury (PRATO-ACS 2) study. NLM identifier: NCT01870804.

45. Baigent $\mathrm{C}$, Landray MJ, Reith C, et al; SHARP Investigators. The effects of lowering LDL cholesterol with simvastatin plus ezetimibe in patients with chronic kidney disease (Study of Heart and Renal Protection): a randomised placebo-controlled trial. Lancet. 2011;377(9784):2181-2192.

46. Fassett RG, Robertson IK, Ball MJ, Geraghty DP, Coombes JS. Effect of atorvastatin on kidney function in chronic kidney disease: a randomised double-blind placebo-controlled trial. Atherosclerosis. 2010;213(1):218-224.

47. Manske CL, Sprafka JM, Strony JT, Wang Y. Contrast nephropathy in azotemic diabetic patients undergoing coronary angiography. Am J Med. 1990;89(5):615-620.

48. Barrett BJ. Contrast nephrotoxicity. J Am Soc Nephrol. 1994;5(2): $125-137$.

49. Parfrey PS, Griffiths SM, Barrett BJ, et al. Contrast material-induced renal failure in patients with diabetes mellitus, renal insufficiency, or both. A prospective controlled study. N Engl J Med. 1989;320(3):143-149.

50. Mehran R, Aymong ED, Nikolsky E, et al. A simple risk score for prediction of contrast-induced nephropathy after percutaneous coronary intervention: development and initial validation. J Am Coll Cardiol. 2004;44(7):1393-1399.

51. Weinrauch LA, Healy RW, Leland OS, et al. Coronary angiography and acute renal failure in diabetic azotemic nephropathy. Ann Intern Med. 1977;86(1):56-59.

52. Kandzari DE, Rebeiz AG, Wang A, Sketch MH. Contrast nephropathy: an evidence-based approach to prevention. Am J Cardiovasc Drugs. 2003;3(6):395-405

53. Patti G, Ricottini E, Nusca A, et al. Short-term, high-dose atorvastatin pretreatment to prevent contrast-induced nephropathy in patients with acute coronary syndromes undergoing percutaneous coronary intervention (from the ARMYDA-CIN [atorvastatin for reduction of myocardial damage during angioplasty - contrast-induced nephropathy] trial. Am J Cardiol. 2011;108(1):1-7.

54. Khanal S, Attallah N, Smith DE, et al. Statin therapy reduces contrastinduced nephropathy: an analysis of contemporary percutaneous interventions. Am J Med. 2005;118(8):843-849.

55. Zhang L, Zhang L, Lu Y, et al. Efficacy of statin pretreatment for the prevention of contrast-induced nephropathy: a meta-analysis of randomised controlled trials. Int J Clin Pract. 2011;65(5):624-630. 
56. Pappy R, Stavrakis S, Hennebry TA, Abu-Fadel MS. Effect of statin therapy on contrast-induced nephropathy after coronary angiography: a meta-analysis. Int J Cardiol. 2011;151(3):348-353.

57. Todorovic Z, Nesic Z, Stojanović R, et al. Acute protective effects of simvastatin in the rat model of renal ischemia-reperfusion injury: it is never too late for the pretreatment. J Pharmacol Sci. 2008;107(4): $465-470$.

58. Holdaas H, Fellström B, Jardine AG, et al; Assessment of LEscol in Renal Transplantation (ALERT) Study Investigators. Effect of fluvastatin in cardiac outcomes in renal transplant recipients: a multicentre, randomised, placebo-controlled trial. Lancet. 2003;361(9374): 2024-2031.

59. Palmer SC, Navaneethan SD, Craig JC, et al. HMG CoA reductase inhibitors (statins) for kidney transplant recipients. Cochrane Database Syst Rev. 2014;1:CD005019.

60. Reiling J, Johnson DW, Kruger PS, Pillans P, Wall DR. Association of pre-transplant statin use with delayed graft function in kidney transplant recipients. BMC Nephrol. 2012;13:111.
61. Randomized, double-blind, parallel-grp, anti-inflammatory and renoprotective effect of pretreatment loading dose atorvastatin in coronary artery bypass graft surgery. NLM identifier: NCT01547455.

62. Randomized, double-blind, parallel-grp. Short-term atorvastatin's effect on acute kidney injury following cardiac surgery. NLM identifier: NCT00791648.

63. Randomized, double-blind, parallel-grp. Preventive effect of the pretreatment with pitavastatin on contrast-induced nephropathy in patients with renal dysfunction undergoing coronary angiography/ intervention (PRINCIPLE-II) study. NLM identifier: NCT 01871792.

64. Randomized, double-blind, parallel-grp. Study of atorvastatin dose dependent reduction of proteinuria. (SARP) study. NLM identifier: NCT 00768638.

65. Randomized, double-blind, parallel-grp. Efficacy of statins in prevention of contrast-induced nephropathy. (SCIN) study. NLM identifier: NCT 01071993.

\section{Publish your work in this journal}

The International Journal of Nephrology and Renovascular Disease is an international, peer-reviewed open-access journal focusing on the pathophysiology of the kidney and vascular supply. Epidemiology, screening, diagnosis, and treatment interventions are covered as well as basic science, biochemical and immunological studies. The journal welcomes original research, clinical studies, reviews \& evaluations, expert opinion and commentary, case reports and extended reports. The manuscript management system is completely online and includes a very quick and fair peerreview system, which is all easy to use. Visit http://www.dovepress.com/ testimonials.php to read real quotes from published authors.

Submit your manuscript here: http://www.dovepress.com/international-journal-of-nephrology-and-renovascular-disease-journal 